\title{
HUBUNGAN PENELITI DAN ANALIS KEBIJAKAN DALAM PEMBUATAN REKOMENDASI KEBIJAKAN PADA BADAN PENELITIAN DAN PENGEMBANGAN HUKUM DAN HAM
}

(The Relationship of The Researcher and Policy Analysis in The Making of

Policy Recommendations in Legal and HAM Research and Development Agency)

\author{
Willy Wibowo \\ Balitbang Hukum dan HAM \\ Kementerian Hukum dan HAM R.I, Jakarta \\ willywibowo70@gmail.com
}

Tulisan Diterima: 31-08-2019; Tulisan Direvisi: 29-02-2020; Disetujui Diterbitkan: 05-03-2020

DOI: http://dx.doi.org/10.30641/kebijakan.2020.V14.75-90

\begin{abstract}
ABSTRAK
Untuk memajukan kebijakan di lingkungan Kementerian Hukum dan HAM RI berbasis riset salah satunya dengan memperkuat unsur sumber daya manusia unggul di bidang teknis kebijakan pada Badan Penelitian dan pengembangan Hukum dan HAM. Peneliti dan analis kebijakan memiliki posisi strategis dalam menjawab tantangan tersebut. Namun, belum banyak yang mengetahui peran analis kebijakan, tugas dan fungsi dalam pembuatan rekomendasi kebijakan, karena jabatan fungsional ini baru di lembaga penelitian dan pengembangan. Penelitian ini bertujuan untuk memberi gambaran perbandingan peran antara peneliti dan analis kebijakan dalam pembuatan rekomendasi kebijakan, serta melihat gap rekomendasi kebijakan serta hubungan analis kebijakan dengan peneliti pada Badan Penelitian dan Pengembangan Hukum dan HAM. Penelitian ini menggunakan metode kualitatif dengan pendekatan studi komparatif. Penelitian ini menunjukkan bahwa peneliti dan analis kebijakan mempunyai peran yang berbeda dalam pembuatan rekomendasi kebijakan, perbedaan terlihat pada sisi tugas pokok dan output. Penelitian ini menghasilkan beberapa rekomendasi kepada Badan Penelitian dan Pengembangan Hukum dan HAM.
\end{abstract}

Kata kunci: peneliti; analis kebijakan; rekomendasi.

\begin{abstract}
One of the ways to advance policies in the Ministry of Law and Human Rights environment is to strengthen the superior human resources in the technical policy field at the Law and Human Rights Research and Development Agency. Researchers and policy analysts have a strategic position in responding to these challenges. However, not many people know the role of policy analysts, tasks and functions in making policy recommendations, because this functional position is only in research and development institutions. This study aims to provide a comparative picture of the role of researchers and policy analysts in making policy recommendations, as well as looking at the gap of policy recommendations and the relationship between policy analysts and researchers at the Legal and Human Rights Research and Development Agency. This research uses a qualitative method with a comparative study approach. This study shows that researchers and policy analysts have different roles in making policy recommendations, differences are seen in terms of the main tasks and outputs. This research resulted in several recommendations to the Legal and Human Rights Research and Development Agency.
\end{abstract}

Keywords: researchers; policy analysts; recommendations. 


\section{PENDAHULUAN}

\section{Latar Belakang}

Badan Penelitian dan Pengembangan Hukum dan Ham (Balitbangkumham) telah merencanakan dan memproyeksikan sasaran kinerja pada tahun 2020 sampai 2024, terwujudnya perumusan kebijakan Kementerian Hukum dan Ham (Kemenkumham RI) berbasis riset ${ }^{1}$. Berdasarkan hal tersebut Balitbangkumham mempunyai tugas menyelenggarakan dukungan substantif dalam bidang penelitian dan memberikan rekomendasi kebijakan kepada seluruh unsur organisasi di lingkungan Kemenkumham RI.

Balitbangkumham sebagai lembaga riset jika dianalogikan sebagai otak dalam tubuh manusia, begitu pula dalam organisasi Balitbangkumham sebagai unit think thank yang berperan membuat rekomendasi kebijakan bagi unit utama dan stakeholder di lingkungan Kemenkumham RI.

Untuk merealisasikan hal tersebut Balitbangkumham telah melakukan upaya penataan organisasi yang bertujuan sebagai unsur supporting substantif tugas Kemenkumham RI, serta menjadi organisasi yang sinergi dengan tugas dan fungsi setiap unit Eselon I di Kemenkumham RI. Proses penataan ulang dimulai dengan penyampaian surat usulan Perubahan Organisasi dan Tata Laksana Balitbangkumham Nomor: PPH.1UM.01.01-281 Tanggal 12 Februari 2019 ke Sekertaris Jenderal Kemenkumham RI.

Ditambah lagi dengan adanya kebijakan Presiden Joko Widodo tentang penyederhanaan birokrasi eselon 3 dan 4 serta Peraturan Menteri Pendayagunaan Aparatur Negara dan Reformasi Birokrasi Republik Indonesia (KemenpanRB) Nomor 28 Tahun 2019 tentang Penyetaraan Jabatan

1 Pusbangdatin Balitbangkumham, Policy Paper Evaluasi Organisasi Dan Tata Kerja Balitbangkumham (Jakarta, 2019).
Administrasi ke dalam Jabatan Fungsional. Dengan adanya kebijakan ini akan banyak penambahan fungsional analis kebijakan pada Balitbangkumham yang semakin memperkuat dalam pembuatan rekomendasi kebijakan

Dalam konsep penyusunan dan penataan organisasi lembaga/badan litbang, diharapkan dapat mengakomodir seluruh kepentingan stakeholders maupun tuntutan zaman dan restrukturisasi tersebut harus tetap berpegang pada kebijakan atau peraturan pemerintah dan harus dapat mencerminkan tugas dan fungsi dalam ruang lingkup yang jelas ${ }^{2}$.

Selain perlunya relevansi hasil litbang (sesuai dengan tujuan dan kebutuhan pengguna), juga perlu didukung oleh sumber daya manusia (SDM) dan anggaran). Sehingga rekomendasi hasil litbang untuk pembuatan kebijakan dapat dimanfaatkan oleh seluruh Unit Eselon I.

Dalam hal ini yang dimaksud dukungan SDM yaitu berupa dukungan keahlian untuk penyediaan analisis informasi yang objektif, aktual dan faktual untuk dijadikan rekomendasi kebijakan. Saat ini Balitbangkumham selain memiliki aplikasi big data artificial intelligence (Sistem Informasi Penelitian Hukum dan HAM), juga adanya fungsional peneliti dan analis kebijakan yang berperan untuk melaksanakan dukungan keahlian tersebut Pada saat ini pembuatan rekomendasi kebijakan belum secara maksimal melibatkan analis kebijakan, hal ini dikarenakan analis kebijakan merupakan fungsional baru pada Balitbangkumham.

Pada saat penaatan organisasi Balibangkumham dan penyederhanaan birokrasi merupakan momentum untuk mendesain pembagian peran antara peneliti

2 Trisapto Wahyu Agung Nugroho, "Reposisi Dan Transformasi Organisasi Litbang Kementerian Hukum Dan HAM," Jurnal IImiah Kebijakan Hukum 7, no. 1 (2013): 62-71. 
dan analis kebijakan, walaupun bukan perkara mudah. Jika tidak di lakukan, bisa jadi pekerjaan para analis kebijakan tidak mendapat angka kredit, yang pada gilirannya menghambat pola karier fungsional analis kebijakan, dilema inilah yang harus diselesaikan oleh organisasi ini.

Penelitian sebelumnya yang dilakukan oleh Zamzam Muhammad Fuad menjelaskan peran peneliti dan analis kebijakan dalam pembentukan prolegnas dan Rancangan Undang-Undang (zamzam, 2017) ${ }^{3}$ dan Syarif Budiman dengan judul analisis hubungan antara hukum dan kebijakan publik : studi pembentukan UU No. 14 Tahun $2008^{4}$. Penelitian yang akan disajikan penulis berbeda dengan penelitian yang sudah ada, karena penelitian ini mengulas perbandingan tugas peneliti dan analis kebijakan, serta gap antara rekomendasi yang dihasilkan dengan rekomendasi dimanfaatkan dan hubungan peneliti dengan analis kebijakan.

Penelitian ini sangat penting dikarenakan bertepatan dengan momentum penataan organisasi dan penyederhanaan birokrasi pada Balitbangkumham, mengingat saat ini sudah ada fungsional analis kebijakan.

\section{Rumusan Masalah}

Berdasarkan penjelasan dari latar belakang di atas, rumusan masalahnya adalah sebagai berikut:

1. Bagaimana perbandingan peran peneliti dan analis kebijakan?

2. Bagaimana gap antara rekomendasi yang dihasilkan dengan rekomendasi yang dimanfaatkan pada Balitbangkumham ?

3 Zamzam Muhammad Fuad, "Peran Peneliti Dan Analis Dalam Pembentukan Prolegnas Dan RUU DI Setjen DPD RI," Jurnal Wacana Kerja 20 (2017): 33-50.

4 Syarif Budiman, "Analisis Hubungan Antara Hukum dan Kebijakan Publik : Studi Pembentukan UU NO . 14 TAHUN 2008 ( Analysis of Relation Between Law and Public Policy : Abstrak," Jurnal Ilmiah Kebijakan Hukum 2008, no. 14 (2017): 109-119.
3. Bagaimana hubungan peneliti dengan analis kebijakan dalam membuat rekomendasi kebijakan?

\section{Tujuan}

Untuk mengetahui dan menganalisis, perbandingan peran peneliti dan analis kebijakan, gap antara rekomendasi yang dihasilkan dengan rekomendasi yang dimanfaatkan dan hubungan peneliti dan analis kebijakan pada Balitbangkumham.

\section{Metode Penelitian}

\section{Pendekatan Penelitian}

Penelitian ini menggunakan pendekatan kualitatif, dengan metode penelitian studi komparatif. membandingkan suatu objek dengan objek lain. Dengan metode ini, penulis menginterpretasikan segala data dan peristiwa yang ada untuk mengonstruksi makna-makna yang dibutuhkan dalam memahami dan menjawab permasalahan penelitian.

\section{Metode Pengumpulan Data}

Pengumpulan bahan-bahan informasi dilakukan dengan menginventarisasi peraturan perundang-undangan, meneliti bahan pustaka (tulisan dan hasil karya tulis ilmiah), dan sumber-sumber bahan lainnya (laporan dan paparan) yang ada relevansinya dengan isu dalam penelitian ini ${ }^{5}$.

\section{Teknik Analisa Data}

Proses analisis data dalam kajian ini menggunakan teknik analisis data yang diadaptasi dari Creswell. Pertama, mengolah dan mempersiapkan data. Kedua, membaca keseluruhan data. Ketiga, memulai coding semua data. Keempat, menginterpretasikan data ${ }^{6}$.

$5 \quad$ Anthon F Susanto, Metodologi Penelitian Hukum (Jakarta, 2014).

6 J. D. Creswell, Kualitatif (yogyakarta: Pustaka Pelajar, 2016). 


\section{PEMBAHASAN}

\section{Perbandingan peran Peneliti dan Analis Kebijakan}

Dalam ilmu ekonomi kita tentunya pernah diajarkan tentang prinsip ekonomi yang menyatakan bahwa dalam menghasilkan barang dan jasa sebisa mungkin dilakukan dengan sumber daya sekecil-kecilnya untuk menghasilkan keuntungan sebesarbesarnya. Oleh karena itu, Kemenkumham $\mathrm{RI}$ diharuskan membuat pilihan prioritas kebijakan yang harus dilaksanakan untuk mencapai pelayanan publik sebesarbesarnya. Untuk mendukung pemilihan kebijakan tersebut, dapat dicapai dengan menggunakan Evidence Based Policy (EBP) atau kebijakan berbasis bukti.

Menurut Menteri Hukum dan HAM, Yasona $\mathrm{H}$. Laoly, untuk mendukung prinsip good goovernance dibutuhkan EBP making, dititik inilah penelitian yang berkualitas menaruh peran pentingnya ${ }^{7}$. Bukti mencakup pengetahuan pakar, hasil penelitian yang dipublikasikan, statistik, konsultasi dengan pemangku kepentingan evaluasi kebijakan sebelumnya, internet, hasil-hasil dari konsultasi. EBP pada saat ini semakin dinilai penting dan menjadi tuntutan bahkan wajib. Karena salah satu dasar bukti yang mampu memperkuat kebijakan adalah hasil penelitian. Pembuatan kebijakan tanpa didasari kajian penelitian akan menghasilkan kebijakan yang akan menimbulkan masalah, seperti:

1. Kebijakan yang tumpah tindih;

2. Kebijakan yang memicu konflik;

3. Adanya intervensi dari pihak-pihak tertentu;

4. Kebijakan yang tidak relevan.

Perubahan paradigma dalam pembuatan kebijakan berbasis bukti membuka peluang

7 Balitbangkumham, "EBP Making," last modified 2018, http://www.balitbangham.go.id/detailpost/ buka-raker- balitbang-hukum-dan-ham-yasonnalaoly-dorong-peneliti- lebih-produktif. bagi para peneliti untuk menjadi bagian dalam penyusunan kebijakan melalui kerja sama dengan para pembuat kebijakan, diperlukan suatu sistem untuk memastikan agar hasil penelitian dapat sampai ke para pembuat kebijakan sehingga hasil penelitiannya dapat digunakan secara efektif.

Dasar hukum penggunaan penelitian sebagai dasar pembuatan kebijakan sudah diatur pada Undang-undang RI Nomor 12 Tahun 2011 tentang pembentukan Peraturan Perundang-undangan yang mengatur bahwa dalam penyusunan peraturan Perundangundangan selain harus melibatkan perancang peraturan perundang-undangan juga harus melibatkan peneliti.

Balitbangkumham sebagai unit utama di lingkungan Kemenkumham RI mempunyai tugas melaksanakan penelitian dan pengembangan di bidang hukum dan hak asasi manusia. Sebagai lembaga penelitian di bidang hukum dan hak asasi manusia mempunyai peran yang sangat strategis dalam mendukung kualitas produk hukum dan kebijakan yang dikeluarkan di lingkup Kemenkumham RI.

Berdasarkan Peraturan Menteri Hukum dan Hak Asasi Manusia Nomor 6 Tahun 2016 tentang Perubahan Atas Peraturan Menteri Hukum dan Hak Asasi Manusia Nomor 29 Tahun 2015 tentang Organisasi dan Tata Kerja Kementerian Hukum dan Hak Asasi Manusia.

Balitbangkumham mempunyai fungsi, adapun fungsinya meliputi:

1. Penyusunan kebijakan teknis, program dan anggaran, pengkajian, penelitian dan pengembangan di bidang hukum dan hak asasi manusia;

2. Pelaksanaan pengkajian, penelitian, dan pengembangan di bidang hukum dan hak asasi manusia;

3. Pemantauan, evaluasi dan pelaporan pelaksanaan pengkajian, penelitian dan 
pengembangan di bidang hukum dan hak asasi manusia; dan

4. Pelaksanaan administrasi Badan Penelitian dan Pengembangan Hukum dan Hak Asasi Manusia;

5. Pelaksanaan fungsi lain yang diberikan oleh Menteri.

Dari beberapa fungsi tersebut Balitbangkumham, menghasilkan ${ }^{8}$ :

1. Rekomendasi hasil penelitian dan pengembangan dibidang Hukum, HAM serta kebijakan;

2. Karya Tulis IImiah (KTI) dalam jurnal ilmiah dan buku maupun media lainnya.

Rekomendasi inilah yang dijadikan dasar untuk membuat suatu kebijakan yang efektif dan efisien, penggunaan EBP dapat mengurangi pemborosan anggaran memperluas program inovatif dan meningkatkan akuntabilitas.

Hasil dari litbang ini menjadi sebuah peluang pemanfaatan berupa rekomendasi hasil litbang digunakan untuk penyusunan peraturan atau kebijakan yang dibuat unit utama. Juga bisa dijadikan pengembangan profesi perancang undang-undang dan penyuluhan hukum, kemudian KTI dapat dimanfaatkan oleh kalangan akademis untuk bahan penyusunan skripsi, tesis dan disertasi.

Sebagaimana diamanatkan Peraturan Menteri Hukum dan HAM Nomor 44 tahun 2015 tentang pemanfaatan hasil penelitian dan pengembangan di bidang Hukum dan HAM.

\section{Pasal 3:}

1. Hasil penelitian dan pengembangan dibidang Hukum dan HAM sebagaimana dimaksud dalam pasal 2 wajib dimanfaatkan oleh unit utama di lingkungan Kementerian Hukum dan HAM;

8 Paparan coaching zona integritas pokja pelayanan publik Balitbangkumham, (dilihat pada tanggal 22 Juli 2019)
2. Selain dimanfaatkan oleh unit utama dilingkungan kementerian Hukum dan HAM sebagaimana dimaksud pada ayat (1), hasil penelitian dan pengembangan dapat dimanfaatkan oleh pemangku kepentingan;

3. Pemangku kepentingan sebagaimana dimaksud pada ayat (2) terdiri atas: a. instansi pemerintah baik ditingkat pusat maupun daerah; dan b. masyarakat.

Untuk menyelesaikan tugas dan fungsi tersebut Balitbangkumham memiliki dukungan SDM yang berjumlah 209.

Tabel.1: Rencana Jumlah Fungsional Peneliti dan Analis Kebijakan Tahun 2020

\begin{tabular}{lll}
\hline No. & \multicolumn{1}{c}{ Jabatan } & Jumlah \\
\hline 1. & Fungsional Peneliti & 59 \\
2. & Fungsional Analis Kebijakan & 34 \\
Sumber: diolah penulis, 2019 &
\end{tabular}

Adanya 2 (dua) fungsional Peneliti dan Analis Kebijakan pada Balitbangkumham, menjadi pembahasan menarik karena kedua fungsional ini secara umum mempunyai tugas di bidang Kebijakan, untuk mengetahui lebih jelasnya, penulis akan melakukan perbandingan tugas antara peneliti dan analis kebijakan.

Dalam melihat perbandingan peneliti dengan analis kebijakan, dapat diperoleh dari analisa, etika kolektif dan aturan perundangundangan.

Jenis kajian kebijakan (policy analysis) berbeda dengan jenis kajian penelitian dasar (basic research). Secara metodologi, kajian kebijakan dan penelitian dasar dapat dibedakan dalam 4 kategori utama, yaitu tujuan, alat analisis, kerahasiaan, dan gaya komunikasi9.

$9 \quad$ A. Etzioni, The Unique Methodology of Policy Research. In M. Moran, M. Rein, \& R. E. Goodin (Eds.), The Oxford Handbook of Public Policy (Oxford: Oxford University Press, 2006). 
JIKH Vol. 14, No. 1, Maret 2020: 75-90

p-ISSN: 1978-2292 - e-ISSN: 2579-7425

Tujuan penelitian peneliti untuk memahami keadaan, sementara analis kebijakan untuk mengubah keadaan. Analogi dapat dijelaskan sebagai berikut, peneliti menjalankan tugasnya untuk mengumpulkan dan menganalisis masalah kemudian analis kebijakan bertugas memperkuat topik kebijakan tersebut dengan kajian kebijakan.

Alat analisis yang digunakan oleh peneliti cakupannya bersifat terbatas, contohnya seperti peneliti hukum tidak boleh menggunakan analisis budaya politik untuk memahami harusnya menggunakan analisis hukum juga. Berbeda dengan analis kebijakan lebih multi disiplin jadi bisa saja seorang analis menggunakan seluruh ilmu yang dimilikinya untuk menjawab sebuah persoalan kebijakan.

Kerahasian, seorang analis kebijakan, hasil kajiannya memiliki sifat rahasia, karena kajian itu ditujukan kepada para pemangku kepentingan tertentu. Sedangkan peneliti harus membuka hasil penelitiannya kepada publik, dengan cara mengundang pihakpihak terkait untuk paparan laporan akhir serta reviewer eksternal. Berikut rangkuman perbandingan Etika Peneliti dan analis Kebijakan.Darisisigayakomunikasi,penelitian dasar biasanya menggunakan bahasa yang cenderung eksklusif, menggunakan konsepkonsep abstrak bahkan kadang-kadang kuantitatif. Walaupun terbuka terhadap publik, penelitian dasar cenderung hanya dibaca oleh kalangan profesi saja atau dunia akademisi, penelitian dasar. Hal ini berbeda dengan kajian kebijakan. Sekalipun sifatnya rahasia, gaya komunikasi penulisan kajian kebijakan lebih kepada publik (baca: luwes) daripada penelitian dasar, adapun perbandingan etika di sebagai berikut:

Tabel. 2 Perbandingan Etika Peneliti dan Analis kebijakan

\begin{tabular}{|c|c|c|}
\hline Kategori & Peneliti & Analis Kebijakan \\
\hline Etika & Saintifikasi Politik & Politisasi Sains \\
\hline Output & Basic Research & Policy analysis \\
\hline Tujuan & Memahami keadaan & Mengubah Keadaan \\
\hline Tuntutan & $\begin{array}{l}\text { Akurasi dan Kebaruan, variabel, metode } \\
\text { dan teori }\end{array}$ & Akurasi dan Kecepatan \\
\hline $\begin{array}{l}\text { Penggunaan } \\
\text { Variabel }\end{array}$ & Variabel digunakan secara ketat & Variabel digunakan secara lunak \\
\hline Alat analisis & Expertise & Multidisipliner \\
\hline Kerahasiaan & Terbuka untuk umum & Rahasia \\
\hline Gaya bahasa & Kaku & Luwes \\
\hline
\end{tabular}

Setelah membahas perbandingan peneliti dan analis kebijakan berdasarkan etika intelektual, kemudian perbandingan dilanjutkan dengan analisis secara peraturan perundang-undangan.

Tugas peneliti dijelaskan secara lengkap dalam peraturan Lembaga IImu Pengetahuan (LIPI) Nomor 14 Tahun 2018 tentang Petunjuk Teknis Jabatan Fungsional Peneliti. bahwa Peneliti adalah PNS yang diberi tugas, tanggung jawab, wewenang, dan hak secara penuh oleh pejabat yang berwenang untuk melakukan tugas teknis penelitian, pengembangan, dan/atau pengkajian ilmu pengetahuan dan teknologi pada organisasi penelitian, pengembangan, dan/atau pengkajian instansi pemerintah.

Penelitian adalah kegiatan yang dilakukan menurut metodologi ilmiah untuk memperoleh data dan informasi yang berkaitan dengan pemahaman tentang fenomena alam dan/atau sosial, pembuktian kebenaran atau ketidakbenaran suatu asumsi 
dan/atau hipotesis, dan penarikan kesimpulan ilmiah.

Pengembangan adalah kegiatan untuk peningkatan kemanfaatan dan daya dukung ilmu pengetahuan dan teknologi yang telah terbukti kebenaran dan keamanannya untuk meningkatkan fungsi dan manfaat ilmu pengetahuan dan teknologi.

Sedangkan tugas analis kebijakan, berdasarkan peraturan Kepala Lembaga Administrasi Negara (LAN) Nomor 14 Tahun 2016 tentang petunjuk teknis penilaian kualitas hasil kegiatan analis kebijakan, fungsional analis kebijakan adalah jabatan fungsional tertentu yang mempunyai ruang lingkup, tugas, tanggung jawab, dan wewenang untuk melaksanakan kajian dan analisis kebijakan dalam lingkungan instansi pusat dan daerah.

Menurut Peraturan Kepala Lembaga Administrasi Negara Nomor 14 tahun 2016 tugas analis kebijakan adalah memberi masukkan dalam proses penyusunan kebijakan, proses penyusunan RUU baik berupa Policy Brief, Policy Memo, naskah akademik. Peran analis kebijakan, adalah Produksi dan Manajer pengetahuan rekomendasi Kebijakan, pengembangan kompetensi dan profesi serta advokasi kebijakan $^{10}$.

Analisis kebijakan ialah proses atau kegiatan menyintesis informasi, termasuk hasil-hasil penelitian, untuk menghasilkan rekomendasi opsi desain kebijakan publik. Dari definisi di atas kiranya dapat dirumuskan karakteristik dasar analis kebijakan ${ }^{11}$, sebagai berikut:

1. Analisis kebijakan merupakan suatu proses atau kegiatan "sintesis" informasi yang berarti pemaduan berbagai informasi, termasuk hasil penelitian,

10 A. Dwiyanto, Mengembalikan Kepercayaan Publik Melalui Reformasi Birokrasi (Jakarta: Gramedia., 2011).

11 B.W. and L.A. Gunn Hogwood, Policy Analysis for the Real World. (Oxford: Oxford University Press, 1988). sehingga diperoleh suatu kesimpulan yang selaras. Hal ini berarti obyek analisis kebijakan ialah proses penyusunan dan paket kebijakan. Kegiatan utama analisis kebijakan ialah pengumpulan informasi secara sistematis dan penarikan kesimpulan logis dari informasi tersebut. Dengan demikian, analisis kebijakan berdasarkan pada kaidah ilmiah;

2. Salah satu sumber utama informasi yang menjadi bahan analisis kebijakan ialah hasil-hasil penelitian. Hal ini berarti bahwa analisis kebijakan merupakan proses pengolahan lebih lanjut dari hasilhasil penelitian sehingga siap digunakan dalam pengambilan keputusan dan desain kebijakan publik. Oleh karena itu, analisis kebijakan merupakan salah satu bentuk diseminasi hasil-hasil penelitian;

3. Output analisis kebijakan ialah rekomendasi opsi keputusan atau desain kebijakan publik. Hal ini berarti bahwa output kebijakan adalah berupa nasehat atau petunjuk operasional tentang bahan pengambilan keputusan publik bagi spesifik klien. Oleh karena itu, analisis kebijakan haruslah disajikan secara jelas, singkat, padat, lengkap dan seksama;

4. Klien analisis kebijakan ialah para pengambil keputusan kebijakan publik (pemerintah dan DPR) dan kelompok yang berkepentingan (interest groups) atas kebijakan pemerintah tersebut. Klien pengguna analisis kebijakan bersifat spesifik. Hal ini berkaitan langsung dengan output analisis kebijakan yang berupa nasehat tentang kebijakan publik;

5. Analisis kebijakan berorientasi klien (client oriented). Hal ini merupakan implikasi dari sifat analisis kebijakan yang menghasilkan nasehat keputusan siap-guna bagi klien spesifik. Tanpa berorientasi klien analisis kebijakan tak akan mungkin siap guna. Hal ini berarti analisis kebijakan haruslah didasarkan pada "dari, oleh dan untuk klien". Analisis kebijakan hanya dilakukan apabila ada 
permintaan atau "patut diduga" benarbenar dibutuhkan kliennya. Analisis kebijakan didorong oleh kebutuhan mendesak kliennya (client's need push).

Dengan ciri-ciri di atas kiranya dapat terlihat bahwa analisis kebijakan (policy analysis) berbeda dengan penelitian kebijakan (policy research). Perbedaan utama terletak pada obyek tujuan, klien, metode, penyajian dan jadwal waktu (Tabel 3). Secara umum dapat dikatakan bahwa perbedaan ini terutama terletak pada klien: klien analisis kebijakan adalah pengambil keputusan spesifik perorangan dan organisasi (specific client oriented), sedangkan klien penelitian kebijakan tidak bersifat spesifik, yaitu semua pihak yang berkepentingan baik pengambil keputusan, ilmuwan, maupun masyarakat umum.

Hal ini terjadi karena penelitian kebijakan dilakukan berdasarkan prosedur penelitian ilmiah yaitu harus terbuka bagi umum untuk dievaluasi kebenarannya, direplikasi dan digunakan hasilnya. Berbeda dengan itu, analisis kebijakan hanya diperuntukkan bagi klien spesifiknya. Dengan demikian dapatlah dikatakan bahwa analisis kebijakan tidak termasuk katagori penelitian ilmiah, namun haruslah dilakukan secara ilmiah dalam artian harus sistematis, logis dan menggunakan teori ilmiah maupun hasil-hasil penelitian ilmiah.

Hasil penelitian kebijakan merupakan salah satu sumber utama informasi untuk pelaksanaan analisis kebijakan. Oleh karena itu, analisis kebijakan pada dasarnya merupakan salah satu wahana diseminasi hasil-hasil penelitian, termasuk hasil penelitian kebijakan.

Balitbangkumham sudah mempunyai fungsional peneliti dan analis kebijakan, merujuk pada beberapa pertimbangan bahwa peneliti dan analis kebijakan dapat berperan pada tahapan awal perencanaan pembentukan RUU melalui naskah akademik. Menurut Undang-undang Nomor 12 Tahun 2011 tentang pembentukan peraturan perundang-undangan, naskah akademik adalah naskah hasil penelitian atau pengkajian hukum dan hasil penelitian lainnya terhadap suatu masalah tertentu yang dapat dipertanggungjawabkan secara ilmiah mengenai pengaturan masalah tersebut dalam suatu rancangan undang-undang, rancangan peraturan daerah provinsi, kabupaten/kota, sebagai solusi terhadap permasalahan dan kebutuhan hukum masyarakat.

Dalam aturan keputusan Menteri Pemberdayaan Aparatur Negara (Menpan) Nomor KEP/128/M.PAN/9/2004 dan Permenpan RB no. 45 Tahun 2013 tentang Jabatan Fungsional Analis Kebijakan dan Angka Kreditnya disebutkan, analis bertugas melakukan kajian dan analis kebijakan, dalam Peraturan Kepala (Perka) LIPI Nomor 2 Tahun 2014 tentang Petunjuk Teknis Jabatan Fungsional Peneliti diterangkan bahwa tugas utama peneliti, melakukan pengembangan ilmu pengetahuan, maknanya adalah agenda penelitian bagi peneliti bukanlah keputusan politik melainkan pengembangan ilmu.Agenda penelitian biasanya tidak hanya ditentukan oleh masalah kemasyarakatan, tetapi juga harus melihat faktor novelty atau kebaruan penelitian, baik itu dalam metodologi, teori dan hasil penelitian-penelitian sebelumnya.

Naskah akademik lebih tepat dikerjakan oleh analis kebijakan hal ini berkaitan dengan salah satu uraian tugas analis kebijakan memberikan rekomendasi kepada pengambil keputusan untuk menyelesaikan masalah publik. Analis kebijakan tidak diwajibkan untuk membuat penelitian yang mengarah pada pertimbangan novelty, tetapi lebih dituntut untuk penyelesaian masalah-masalah publik.

Saat ini Balitbangkumham belum menjalankan fungsi penyusunan dan penyelarasan naskah akademik, fungsi ini berada di Badan Pembinaan Hukum dan Nasional (BPHN). Diperlukan upaya 
kolaborasi antara Balitbangkumham dengan BPHN dalam pelaksanaan penyusunan dan penyelarasan naskah akademik ${ }^{12}$.

Berdasarkan uraian pada Tabel 3 dapat dicermati bahwa kegiatan utama peneliti adalah membuat karya tulis ilmiah. Selain itu, karya tulis ilmiah harus dipublikasikan. Dengan kata lain ${ }^{13}$, meskipun seluruh kegiatannya membuat karya tulis ilmiah, yang membedakan adalah bentuk publikasinya. Karya tulis ilmiah tersebut dapat diterbitkan oleh penerbit internasional, nasional, dalam majalah ilmiah, dsb. Dalam Perka LIPI Nomor 2 Tahun 2014 tentang Petunjuk Teknis Jabatan Fungsional Peneliti dijelaskan lebih lanjut bahwa yang dimaksud karya ilmiah dapat berupa makalah lengkap, monografi, komunikasi pendek, kajian kebijakan, dan makalah kebijakan.

Tabel.3 Perbandingan Peneliti dan Analis Kebijakan dalam peraturan perundangan

\begin{tabular}{|c|c|c|c|}
\hline Fungsional & Tugas pokok & Sub unsur tugas pokok & Output \\
\hline Peneliti & $\begin{array}{l}\text { Melakukan } \\
\text { penelitian dan } \\
\text { pengembangan ilmu } \\
\text { pengetahuan dan } \\
\text { teknologi }\end{array}$ & $\begin{array}{l}\text { Membuat karya tuis ilmiah } \\
\text { yang terbit dalam : } \\
\text { - Buku oleh penerbit } \\
\text { internasional } \\
\text { - Buku oleh penerbit } \\
\text { nasional } \\
\text { - Bagian dari buku oleh } \\
\text { penerbit internasional } \\
\text { - Bagian dari buku oleh } \\
\text { penerbit nasional } \\
\text { - Majalah ilmiah } \\
\text { internasional } \\
\text { - Majalah ilmiah nasional } \\
\text { terakreditasi } \\
\text { - Prosiding pertemuan } \\
\text { ilmiah }\end{array}$ & $\begin{array}{l}\text { Jenis karya tulis ilmiah : } \\
\text { - Makalah lengkap } \\
\text { - Monografi } \\
\text { - Komunikasi pendek } \\
\text { - Kajian kebijakan } \\
\text { - Makalah kebijakan }\end{array}$ \\
\hline $\begin{array}{l}\text { Analis } \\
\text { Kebijakan }\end{array}$ & $\begin{array}{l}\text { Melaksanakan } \\
\text { kajian dan analisis } \\
\text { kebijakan }\end{array}$ & $\begin{array}{l}\text { - Menyediakan informasi } \\
\text { terkait perumusan } \\
\text { masalah kebijakan } \\
\text { - } \text { Merumuskan isu-isu } \\
\text { kebijakan ke dalam } \\
\text { rumusan masalah } \\
\text { kebijakan } \\
\text { - Melaksanakan } \\
\text { pemantauan dan } \\
\text { evaluasi implementasi } \\
\text { kebijakan } \\
\text { - Penyusunan naskah } \\
\text { akademik }\end{array}$ & $\begin{array}{l}\text { - } \text { Naskah akademik } \\
\text { - } \text { Makalah kebijakan } \\
\text { - } \text { Kajian kebijakan } \\
\text { - } \text { Ringkalah kebijakan } \\
\text { - Laporan hasil } \\
\text { - } \text { Lemantaakan } \\
\text { - } \text { evaluasi } \\
\text { - } \text { Telahaan staf } \\
\text { - } \text { Memo kebijakan }\end{array}$ \\
\hline
\end{tabular}

Sumber: Keputusan Menpan KEP/128/M.PAN/9/2004, dan Peraturan Kepala LIPI No 2 Tahun 2014. dan Permenpan No. 45 Tahun 2013

12 Ahyar Ari Gayo, "Peran Peneliti Dan Pola Koordinasi Penelitian Dalam Rangka Optimalisasi Fungsi Penelitian Dalam Pembentukan Peraturan Perundang-Undangan," Jurnal Hukum dan Peradilan 6, no. 1 (2017): 91.

13 Fuad, "Peran Peneliti Dan Analis Dalam Pembentukan Prolegnas Dan RUU DI Setjen DPD RI." 
JIKH Vol. 14, No. 1, Maret 2020: 75-90

p-ISSN: 1978-2292 - e-ISSN: 2579-7425

\section{Gap antara rekomendasi hasil penelitian dengan rekomendasi yang dimanfaatkan}

Setiap pusat penelitian/pengkajian dan pengembangan wajib menyusun rencana pencapaian kinerja utama penelitian dengan mengacu pada indikator kinerja yang diukur berdasarkan hasil pemetaan kinerja baik dilihat dari sisi keberadaan organisasi maupun kegiatan penelitian itu sendiri. Pada dasarnya, terdapat dua dimensi pengukuran indikator kinerja penelitian yang dilaksanakan oleh Balitbangkumham, yaitu:

1) Indikator kinerja berbasis pengukuran kinerja organisasi berupa jumlah policy brief/paper (rekomendasi kebijakan yang dimanfaatkan;

2) Indikator kinerja berbasis keluaran penelitian.

Indikator yang pertama mencerminkan bagaimana Balitbangkumham berhasil memberikan rekomendasi berbasis hasil penelitian yang dilakukan, diajukan kepada pemangku kepentingan (unit utama di Kemenkumham) terkait sebagai dasar pembuatan kebijakan. Pencapaian rekomendasi kebijakan yang dimanfaatkan mencerminkan komitmen Balitbangkumham untuk mendukung "policy-based research" dan semakin kuatnya kerja sama antara pusat-pusat penelitian/pengkajian di Balitbangkumham dengan para pemangku kepentingan yaitu unit utama di Kemenkumham RI.

Indikator yang kedua, berdasarkan Permenristekdikti Nomor 32 Tahun 2018 tentang Akreditasi perguruan tinggi dan program studi, keluaran penelitian dapat berupa:

1. Publikasi ilmiah;

2. Prototipe;

3. Paten;

4. Kekayaan intelektual;

5. Laporan penelitian.

Sedangkan keluaran yang diharapkan dari sebuah kegiatan penelitian yang dilakukan oleh peneliti di Balitbangkumham adalah berupa:

1. Publikasi ilmiah, meliputi publikasi pada jurnal ilmiah, kumpulan makalah, buku ajar/teks dan sejenisnya yang bersifat ilmiah;

2. Kekayaan intelektual berupa hak cipta;

3. Laporan penelitian yaitu dokumen yang berisi pelaksanaan dan capaian atas keluaran penelitian.

Balitbangkumham sudah menjalankan tugas dan fungsinya hal ini dapat diukur dengan banyaknya jumlah rekomendasi yang dihasilkan. Namun, banyaknya hasil rekomendasi tidak dibarengi dengan rekomendasi yang dimanfaatkan, adanya gap ini pastinya mengurangi nilai target capaian indikator kinerja kegiatan (IKK). Penilaian tingkat capaian IKK dilakukan dengan cara membandingkan antara realisasi capaian rekomendasi hasil litbang yang dimanfaatkan dengan realisasi capaian rekomendasi hasil litbang. (Data pada tabel 4). 
Tabel.4 Rekomendasi hasil penelitian dan pengembangan Tahun 2018

\begin{tabular}{lcccc}
\hline & \multicolumn{2}{c}{$\begin{array}{c}\text { Rekomendasi Litbang yang } \\
\text { dihasilkan }\end{array}$} & \multicolumn{2}{c}{$\begin{array}{c}\text { Rekomendasi Litbang yang } \\
\text { dimanfaatkan }\end{array}$} \\
\cline { 2 - 5 } & $\begin{array}{c}\text { Pemangunan } \\
\text { Pukum } \\
\text { Nasional }\end{array}$ & $\begin{array}{c}\text { Perumusan } \\
\text { Kebijakan }\end{array}$ & $\begin{array}{c}\text { Pembangunan } \\
\text { Hukum } \\
\text { Nasional }\end{array}$ & $\begin{array}{c}\text { Perumusan } \\
\text { Kebijakan }\end{array}$ \\
\hline Penelitian dan Pengembangan Hukum & 20 & 39 & 11 & 6 \\
Penelitian dan Pengembangan HAM & 52 & 38 & 10 & 6 \\
Pengkajian dan Pengembangan Kebijakan & 34 & 69 & 1 & 38 \\
Pengembangan Data dan Informasi & 9 & 10 & 1 & 10 \\
Penelitian Hukum dan HAM & & & &
\end{tabular}

Menurut data Laporan Kinerja Instansi Pemerintah (LKIP) Balitbangkumham Tahun 2018 gap ini terjadi karena beberapa permasalahan yang dihadapi antara lain:

1. Belum tersosialisasikannya Peraturan Menteri Hukum dan HAM Republik Indonesia Nomor 44 Tahun 2016 tentang Pemanfaatan Hasil Penelitian dan Pengembangan di Bidang Hukum dan HAM kepada unit teknis di lingkungan Kemenkumham RI sehingga hasil penelitian belum termanfaatkan secara optimal;

2. Implementasi Peraturan Menteri Hukum dan HAM Republik Indonesia Nomor 43 Tahun 2016 tentang Pedoman Penelitian dan Pengembangan di Bidang Hukum dan Hak Asasi Manusia di lingkungan Kementerian Hukum dan HAM belum optimal sehingga hasil penelitian kurang memenuhi kebutuhan stakeholder internal Kemenkumham RI;

3. Pengukuran manfaat (outcome) penelitian dan pengembangan belum maksimal karena pemanfaatan hasil litbang sering kali tidak dilakukan pada waktu yang singkat, namun dapat dimanfaatkan pada waktu yang akan datang pada saat pemangku kepentingan membutuhkan;

4. Kurang meratanya pendistribusian hasil-hasil penelitian, pengembangan dan evaluasi serta minimnya kegiatan sosialisasi, sehingga mengakibatkan outcome dari hasil penelitian, pengembangan dan evaluasi tidak maksimal;

5. Struktur organisasi Balitbangkumham belum mencerminkan tugas dan fungsi Unit Eselon I di Kemenkumham RI, jadi arah litbang belum berdasarkan tugas dan fungsi eselon I di Kemenkumham RI.

Menurut hasil analisa penulis, gap yang terjadi pada permasalahan ini bisa saja terjadi karena rekomendasi yang dihasilkan belum dipahami oleh pembuat kebijakan (pemangku kepentingan). Hal ini dikarenakan sering kali rekomendasi hasil litbang sulit diterjemahkan ke dalam bahasa pengambil kebijakan dan juga biasanya tidak ada hubungan langsung peneliti dengan pengguna. Kemungkinan ini bisa saja terjadi karena menurut hasil telaah dokumen, hasil-hasil penelitian yang menggunakan metode kuantitatif sering kali membingungkan terutama hasil litbang masih menggunakan bahasa statistik terkadang sulit dipahami. kemudian selama ini pembuatan rekomendasi pada Balitbangkumham di buat oleh pejabat struktural.

Secara umum permasalahan ini masih mempunyai korelasi dengan tugas peneliti dan analis kebijakan, yaitu hasil litbang yang dihasilkan oleh peneliti

Analis kebijakan perlu memahami bahwa rekomendasi kebijakan mempunyai lima dimensi judgment atau pertimbangan secara nilai untuk membuat keputusan yaitu desain kebijakan publik. Output-nya berupa 
rekomendasi atau petunjuk operasional tentang bahan pengambilan keputusan sebaiknya dilakukan proses pengolahan analisis kebijakan terlebih dahulu sehingga siap digunakan dalam pengambilan keputusan ataupun publik bagi spesifik klien, disajikan secara jelas, singkat, padat, lengkap dan seksama dengan metodologi, manajerial, sosial budaya, politik, legal dan etika.

Kemudian, sebelum dikeluarkan menjadi sebuah rekomendasi kebijakan perlu dilakukan pertimbangan manajerial karena pada akhirnya, kebijakan harus dapat dilaksanakan atau dipraktikkan. Manajerial judgement yang terakhir hanya bersifat stressed test untuk memastikan bahwa kebijakan yang akan dibuat dapat dilaksanakan tanpa mengubah hasil.

Sebagai lembaga riset di bawah naungan Kemenkumham RI, Balitbangkumham harus menghasilkan output yang dapat dimanfaatkan untuk masyarakat. Sesuai dengan Indikator Kinerja Utama yang telah ditetapkan dalam Perjanjian Kinerja antara Menteri Hukum dan HAM dengan Kepala Badan, target capaian kinerja Balitbangkumham. Terukur melalui banyaknya rekomendasi hasil penelitian dan pengembangan hukum dan hak asasi manusia yang dimanfaatkan sebagai bahan pembangunan hukum nasional dan perumusan kebijakan hukum dan hak asasi manusia.

Namun demikian, pemanfaatan rekomendasi hasil dan pengembangan hukum dan hak asasi manusia yang dihasilkan belum maksimal, karena belum semua stakeholder menindaklanjuti rekomendasi yang dihasilkan oleh Balitbangkumham.

\section{Hubungan peneliti dengan analis kebijakan}

Kegiatan penelitian menghasilkan berbagai data penting (investasi yang besar), salah satu hasil litbang yaitu data dan informasi ${ }^{14}$. Dalam pengambilan data dan

$\overline{14}$ Erna Irawati, Slide Analisis Kebijakan Publik Dan informasi memerlukan biaya yang besar karena sebaran responden yang tersebar di beberapa wilayah menghabiskan biaya mahal untuk transportasi dan penginapan.

Biaya yang dikeluarkan sering kali tidak sejalan dengan pemanfaatan hasil litbang salah satu penyebabnya adalah rekomendasi yang dibuat untuk pembuat kebijakan terlalu umum dan luas (tidak spesifik). Perlu dipahami bahwa peneliti dan pengambil kebijakan bekerja dalam arena yang berbeda, komunitas birokrat dan peneliti dalam dunia berbeda ${ }^{15}$ :

1. Pandangan peneliti terhadap birokrat

a. Mereka tidak paham penelitian punya prosedur baku, banyak tahapan, butuh waktu;

b. Mereka membuat kebijakan tidak berdasar fakta dan logika;

c. Mereka tidak realistis, mau dapat jawaban sederhana dan praktis atas masalah rumit;

d. Tidak bisa berbicara dengan mereka, karena beda bahasa;

e. Permintaan mereka bukanlah masalah yang dapat diteliti;

f. Mereka tidak mau mengambil risiko dan ketidakpastian;

g. Mereka mau dilayani penuh tapi tidak peduli peneliti;

h. Mereka menggunakan penelitian untuk kepentingan diri dan golongan;

i. Penelitian hanya sebagai justifikasi dan bela diri mereka;

j. Mereka tidak mempercayai peneliti.

2. Pandangan Birokrat terhadap peneliti

a. Mereka habiskan waktu mengkaji masalah, bahkan yang paling sederhana, lalu terlambat memberi hasil;

Profesi Analis (Jakarta, n.d).

15 Pantjar Simatupang, Materi Penyempurnaan Rumusan Kebijakan Balitbangkumham (Jakarta, 2014). 
b. Entah apa yang mereka tulis, siapa yang paham;

c. Mereka hidup di menara gading, memproduksi pengetahuan dan rekomendasi tidak relevan;

d. Rekomendasi mereka selalu bersyarat dan tidak spesifik;

e. Mereka tidak menjawab pertanyaan yang saya ajukan;

f. Mereka tidak mau mengikuti saran, selalu berganti topik penelitian.

Berikut gap peneliti dengan pembuat kebijakan:

1. Celah pasok (supply gap): penelitian tidak mencukupi kebutuhan pembuat kebijakan;

2. Celah permintaan (demand gap): hasil dan kemampuan penelitian tersedia tapi pembuat kebijakan tidak mau atau tidak mampu memanfaatkan;

3. Celah pemerintahan (governance gap): hukum, peraturan, organisasi atau kelembagaan menghalangi data dan pengetahuan;

4. Celah komunikasi (communication gap): komunikasi peneliti pembuat kebijakan tidak memadai karena keterbatasan interaksi, keterampilan atau pengalaman bekerja sama.

Pembuatan rekomendasi analisis kebijakan (policy brief, policy paper) diharapkan menjadi salah satu jembatan penghubung gap peneliti dengan pembuat kebijakan.

Hubungan antara peneliti dan analis kebijakan dalam pembuatan rekomendasi kebijakan pada Balitbangkumham terletak pada kesamaan proses, yaitu memiliki kesamaan pada prosesnya, sama-sama diawali dengan permasalahan atau fenomena dan sama-sama diakhiri dengan upaya mencari solusi terhadap permasalahan tersebut. Namun, solusinya berbeda, jika solusi dari penelitian yang dilakukan peneliti output-nya adalah basic research atau penelitian dasar dalam bentuk buku ilmiah. Sedangkan solusi dari kajian kebijakan yang dilakukan oleh analis kebijakan adalah analisis kebijakan dalam bentuk ringkasan kebijakan.

Mendukung, dalam proses pembuatan kebijakan publik (formulasi). Proses terjadinya pembuatan rekomendasi kebijakan melalui proses yang di dahului dari pemaduan berbagai informasi, termasuk hasil-hasil penelitian yang dilakukan oleh peneliti. Hal ini berarti bahwa hubungan peneliti dan analis kebijakan saling mendukung karena tanpa adanya hasil-hasil penelitian pembuatan rekomendasi kebijakan tidak valid (evidence based policy).

Menguatkan, setelah proses penelitian selesai di laksanakan kemudian tugas analis kebijakan membuat rekomendasi kebijakan dengan kaidah-kaidah analisis kebijakan. Pada tahapan inilah sebuah penelitian dipertajam kembali agar menjadi sebuah rekomendasi kebijakan.

Dengan demikian hubungan antara peneliti dan analis kebijakan terletak pada adanya kesamaan, saling mendukung dan saling menguatkan. Namun, sejauh ini pembagian tugas pada pembuatan rekomendasi kebijakan pada Balitbangkumham masih dilakukan oleh pejabat struktural sambal menunggu perubahan analis kebijakan existing (peralihan tugas) belum ada aturan yang berisikan pembuatan rekomendasi kebijakan oleh analis kebijakan. Perlu adanya SOP atau aturan yang sebagai dasar fungsional analis kebijakan untuk melakukan pembuatan rekomendasi. Hal ini karena Jabatan fungsional analis kebijakan dirancang untuk menyediakan informasi yang dapat dipercaya oleh pengambil keputusan sebagai bahan pembuatan kebijakan ${ }^{16}$.

16 A. Dwiyanto, Memimpin Perubahan Di Birokrasi Pemerintah (Yogyakarta: UGM Press, 2016). 
JIKH Vol. 14, No. 1, Maret 2020: 75-90

p-ISSN: 1978-2292 - e-ISSN: 2579-7425

Dalam rangka membuat rekomendasi kebijakan perlu adanya dukungan dari peneliti inilah yang disebut sebagai adanya hubungan antara peneliti dengan analis kebijakan. Dukungan inilah yang akan membuat rekomendasi kebijakan memiliki dasar penelitian (bukti penelitian). Tanpa adanya proses tersebut maka akan hilang makna substansinya sehingga rekomendasi kebijakan itu juga akan kurang efektif diimplementasikan.

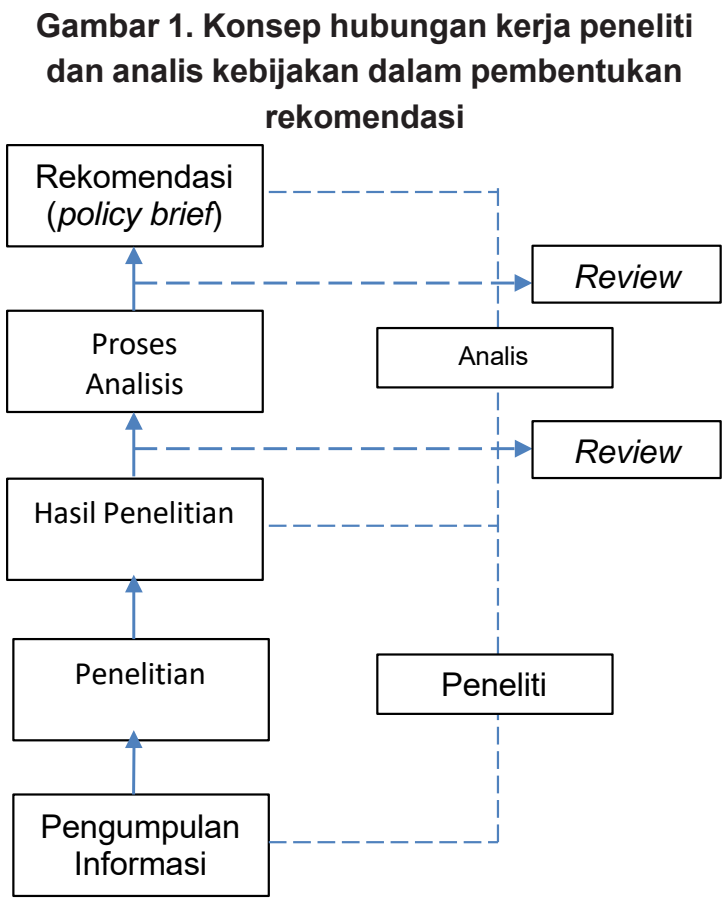

Sumber: diolah penulis

\section{PENUTUP}

\section{Kesimpulan}

Peneliti dan analis kebijakan memiliki peran strategis untuk mewujudkan perumusan kebijakan di Lingkungan Kemenkumham RI berbasis riset. Penelitian ini menunjukkan bahwa terdapat dua perbedaan peran antara peneliti dan analis kebijakan dalam pembuatan rekomendasi kebijakan, Kemudian penelitian ini menjawab penyebab adanya gap antara rekomendasi hasil litbang dengan rekomendasi yang dimanfaatkan, dan yang terakhir menjelaskan hubungan peneliti dengan analis kebijakan dalam pembuatan rekomendasi kebijakan.

Selanjutnya terkait permasalahan kedua yaitu adanya gap antara rekomendasi hasil litbang dengan rekomendasi yang dimanfaatkan. Beberapa penyebab terjadinya gap sudah diuraikan pada pembahasan. Penulis mengungkapkan bahwa adanya kemungkinan karena rekomendasi yang dihasilkan belum dipahami oleh pembuat kebijakan (pemangku kepentingan). Juga, bisa saja terjadi dikarenakan rekomendasi hasil litbang masih menggunakan bahasa akademis ataupun bahasa kuantitatif, serta rekomendasi kurang tajam.

Sejauh ini pembuatan rekomendasi kebijakan masih didominasi oleh pejabat struktural belum ada aturan yang menyebutkan pembuatan rekomendasi

dimaklumi karena analis kebijakan merupakan fungsional baru pada Balitbangkumham dan masih menunggu peralihan tugas analis kebijakan existing.

Pada dasarnya pemanfaatan rekomendasi hasil litbang belum maksimal, bukan merupakan kesalahan Balitbangkumham saja tetapi karena belum semua stakeholder menindaklanjuti rekomendasi yang dihasilkan oleh Balitbangkumham. Beberapa kendala yang menyebabkan hal ini antara lain:

1. Keterbatasan sosialisasi tentang hasil penelitian dan pengembangan hukum dan hak asasi manusia kepada stakeholder dari masing-masing judul penelitian;

2. Penyampaian rekomendasi kepada stakeholder tidak di-follow up lebih lanjut sehingga stakeholder tidak menindaklanjutinya;

3. Adanya kemungkinan stakeholder tidak memberikan respons/tindak lanjut secara formal walau telah menerima atau melaksanakan rekomendasi dari Balitbangkumham; 
4. Dalam pelaksanaannya, ada kemungkinan rekomendasi dari Balitbangkumham tidak dapat dilaksanakan di tahun berjalan karena membutuhkan proses di internal stakeholder sendiri untuk mengimplementasikan rekomendasi tersebut.

Hubungan peneliti dengan analis kebijakan dalam pembuatan rekomendasi kebijakan terletak pada. (1) Kesamaan proses, memiliki kesamaan pada prosesnya, sama-sama diawali dengan permasalahan atau fenomena dan sama-sama diakhiri dengan upaya mencari solusi terhadap permasalahan. (2) mendukung, mendukung dalam proses pembuatan kebijakan publik (formulasi). (3) Menguatkan, setelah proses penelitian selesai dilaksanakan kemudian tugas analis kebijakan membuat rekomendasi kebijakan dengan kaidah-kaidah analisis kebijakan. Pada tahapan inilah sebuah penelitian di pertajam kembali agar menjadi sebuah rekomendasi kebijakan.

Analis kebijakan diharapkan berperan sebagai jembatan penghubung untuk menghilangkan gap antara peneliti dengan pembuat kebijakan (pemangku kepentingan), karena hasil litbang yang mengeluarkan anggaran investasi besar harus mempunyai nilai manfaat yang besar pula. Disinilah tugas analis kebijakan sebagai carpenter (tukang kayu) untuk menghaluskan juga sebagai tukang pisau untuk mempertajam rekomendasi kebijakan agar dimanfaatkan oleh pembuat kebijakan.

\section{Saran}

Balitbangkumham perlu melakukan sebagai berikut:

1. Hendaknya pembuatan rekomendasi kebijakan pada instansi litbang senantiasa menggunakan dasar penelitian (evidence-based policy);

2. Perlunya untuk menyamakan persepsi antara peneliti dan analis kebijakan dalam suatu penelitian yang nanti hasilnya dibuatkan rekomendasi

3. Perlunya pembuatan SOP rekomendasi kebijakan yang selama ini di tugaskan kepada pejabat struktural ke fungsional analis kebijakan;

4. Perlunya menambah kompetensi analis kebijakan perlu diberikan pelatihan teknis terkait kebijakan, pengolahan data agar dapat membuat rekomendasi kebijakan yang berkualitas.

\section{UCAPAN TERIMA KASIH}

Alhamdulillah Wa Syukurillah, penulis panjatkan ke hadirat ALLAH Azzawajalla, atas rahmat dan keberkahan yang senantiasa dilimpahkan. Shalawat serta salam juga tercurahkan kepada Nabi Muhammad Shallallahu'alaihi Wasallam sebagai uswatun hasanah bagi seluruh umat manusia. Penulis mengucapkan terima kasih kepada seluruh keluarga besar Balitbangkumham yang telah membantu dalam menyelesaikan penelitian ini.

\section{DAFTAR PUSTAKA}

Balitbangkumham. "EBP Making." Last modified 2018. http://www. balitbangham. go.id/detailpost/buka-raker- balitbanghukum-dan-ham-yasonna-laoly-dorongpeneliti- lebih-produktif.

Budiman, Syarif. "Analisis Hubungan Antara Hukum dan Kebijakan Publik : Studi Pembententukan UU NO . 14 TAHUN 2008 ( Analysis of Relation Between Law and Public Policy : Abstrak." Jurnal IImiah Kebijakan Hukum 2008, no. 14 (2017): 109-119.

Creswell, J. D. Kualitatif. yogyakarta: Pustaka Pelajar, 2016.

Dwiyanto, A. Memimpin Perubahan Di Birokrasi Pemerintah. Yogyakarta: UGM Press, 2016. - Mengembalikan Kepercayaan Publik Melalui Reformasi Birokrasi. Jakarta: Gramedia., 2011. 
JIKH Vol. 14, No. 1, Maret 2020: 75-90

p-ISSN: 1978-2292 - e-ISSN: 2579-7425

Etzioni, A. The Unique Methodology of Policy Research. In M. Moran, M. Rein, \& R. E. Goodin (Eds.), The Oxford Handbook of Public Policy. Oxford: Oxford University Press, 2006.

Fuad, Zamzam Muhammad. "Peran Peneliti Dan Analis Dalam Pembentukan Prolegnas Dan RUU DI Setjen DPD RI." Jurnal Wacana Kerja 20 (2017): 33-50.

Gayo, Ahyar Ari. "Peran Peneliti Dan Pola Koordinasi Penelitian Dalam Rangka Optimalisasi Fungsi Penelitian Dalam Pembentukan Peraturan PerundangUndangan." Jurnal Hukum dan Peradilan 6, no. 1 (2017): 91.

Hogwood, B.W. and L.A. Gunn. Policy Analysis for the Real World. Oxford: Oxford University Press, 1988.

Irawati, Erna. Slide Analisis Kebijakan Publik Dan Profesi Analis. Jakarta, n.d.

Nugroho, Trisapto Wahyu Agung. "Reposisi Dan Transformasi Organisasi Litbang Kementerian Hukum Dan HAM." Jurnal miah Kebijakan Hukum 7, no. 1 (2013): 62-71.

Pusbangdatin Balitbangkumham. Policy Paper Evaluasi Organisasi Dan Tata Kerja Balitbangkumham. Jakarta, 2019.

Simatupang, Pantjar. Materi Penyempurnaan Rumusan Kebijakan Balitbangkumham. Jakarta, 2014.

Susanto, Anthon F. Metodologi Penelitian Hukum. Jakarta, 2014. 